\title{
Enhancing Visitor Experiences Using Thematic Interpretation in Park Guiding Service in Sarawak National Parks
}

\author{
Victor Luna Amin ${ }^{1}$, Margaret Chan Kit Yok ${ }^{2}$, Mohd Shukri Omar ${ }^{3}$ \\ ${ }^{1}$ Protected Areas and Biodiversity Conservation Division, SARAWAK FORESTRY Corporation Sdn. \\ Bhd., Kuching, Sarawak, Malaysia \\ ${ }^{2}$ Natural Product Research and Development Centre, University of Technology MARA, Jalan \\ Meranek, Kota Samarahan, Sarawak, Malaysia \\ ${ }^{3}$ University of Technology MARA, Kota Bharu Campus, Kelantan, Malaysia
}

\begin{abstract}
Enhancing visitor experiences is arguably the primary and most important goal for interpretation by many protected area managers and tourism business. However, little research has been conducted in Sarawak, Malaysia to directly quantify the effects of thematic interpretation has on tourist experiences. Drawing on the TORE-model of interpretation and through the inception of Park Guiding Training and Licensing System in Sarawak since 2007, this quantitative study examines the effectiveness of thematic interpretive guided tours delivered by park guides at Bako National Park, Sarawak, with the assumption that it will further enhance visitor experiences. A descriptive analysis and Pearson's product-moment correlation analysis of sub-indicators of the global evaluation of interpretation of site, and sub-indicators of elaboration surveyed from visitors of purposively sampled park guides revealed a strong measurement and correlation coefficients of visitors' overall quality of thematic intepretive guided tours effecting visitor satisfaction and experiences. These findings provide empirical evidence that good thematic interpretive guided tour makes a positive impacts on visitor experiences, thus making training of tourism businesses' employees as park guides as a good investment. The suggestions for further research in influencing visitor attitude and shaping visitor behaviour are offered.
\end{abstract}

\section{Introduction}

The strategic roles of thematic interpretation in visitor management of national parks and in the context of tourism as a positive force for conservation and sustainable development are widely acknowledged [1-7]. The first author to define interpretation formally was by Freeman Tilden [8] who defined it as an educational activity which aims to reveal meanings and relationships through the use of original objects, by firsthand experience, and by illustrative media, rather than simply to communicate factual information. In achieving the above wide range of interests in national parks,

Ham and Weiler [9] regarded thematic interpretation as a necessary centrepiece of conservation and sustainable tourism because of it potential to influence visitors' beliefs and actions toward natural and cultural resources, and because of its importance in positively shaping both the nature and quality of visitor experiences. With ecotourism being widely promoted in association with the management of 
protected areas of the developing countries, one of the key strategies for achieving these wide range of these lofty ideals is the frequent reliance of tour guides or park guides to inform, involve and inspire the visitor [2]. It is based on the premise of this relationship, the protected areas managers and private tourism business had invested in training of their employees as interpretive guides.

In an effort to enhance the quality of park guiding services, like the rest of the developing countries, as Sarawak's national parks are getting matured with time and increased use levels of ecotourism sites, coupled with cuts to management resources, Sarawak has since 2007, through Section 7 and 8 of the state National Parks and Nature Reserves Regulations 1999, developed and implemented a Park guiding Training and Licensing System, with thematic interpretation being adopted as a standard approach for delivering the park guiding services in Sarawak national parks. Prior to the adoption of thematic approach of interpretation, park guides' roles were limited to just showing the way, giving factual information and ensuring the safety of visitors. The Controller of National Parks and Nature Reserves appointed Sarawak Forestry Corporation as a training provider who then assigned University of Technology MARA as a training consultant to deliver the 2-week intensive skill-based Park Guide Training Programme called "Certificate in Park Guiding Training Course" approved by Controller. The training programe is specially tailored to meet the increasing demands of providing quality guiding services in Sarawak's national parks. The components of modules of park guiding training course include (i) theoretical knowledge on tourism and ecotourism, (ii) totally protected areas management system, (iii) national parks and nature reserves as tourism products (concept of tropical rainforests, economical and ecological values of plants, wildlife and geological landforms), (iv) risk management, and (v) principle of thematic interpretation.

However, since the diffusion and adoption of this innovative approach of interpretive communication becomes known, tried and put into practice by park guides since 2007, the training effectiveness to precisely quantify the influence that the thematic interpretation have on visitor experiences has not been evaluated. The purpose of this study is to examine the effects of thematic interpretive guided tours, delivered by purposively selected trained park guides at Bako National Park, Sarawak, with the assumption that it will enhance visitor experiences in the context of affective outcomes - what visitors might feel as a result of interpretation (e.g., satisfaction with something, an attitude with something). The findings of this study is essential to ensure that the park guiding training programme is meeting the needs of the industry, employers and trainees, and to ensure that the programme is kept current and relevant to changes in an ever-changing industry [10].

\section{Enhancing Visitor Experience}

Visitor experience has been of great interest in many national park management for the last few decades, based on the premise that high visitor satisfaction contributes to increase numbers, positive word of mouth and political support [11]. According to Ham and Sanberg [5], in experiential psychology, "experience", was seen as what captured in tourists' minds as they go about the act of being a tourist. It was the total sum of their thoughts and emotion - what they were thinking and how they were feeling - as they engaged in the things they do during their travels. So "experience" according to Ham [12] was nothing more than thinking, and the more visitors were provoked to think to have personal thoughts and to make personal meanings (meaning making) about a place or thing, the more profound were their experiences. He terms this meaning making as a memory making experience, and argued that every interpretive guide who succeeds as a facilitator of meaning making also succeeds in memory making [25]. According to Ham, the main way the guides can enhance visitors' experiences was to influence how much those people think, what they think about, and how they feel about it through interpretation. Thus, Ham pointed out that one way to evaluate the quality or effectiveness of the interpretive aspects of a guided tours would be to pay attention to how much the guides provoke their visitors to have personal thoughts and to make personal meanings about what a place, thing, a person or a concept, rather than paying attention to how much factual knowledge the visitors acquire or can later remember, and by doing so, it helped to shape that person experiences. He 
added that if the thoughts the person thinks were pleasing or gratifying in some way, her or his experience, by definition, had been enhanced [13].

\section{Thematic Interpretation}

Interpretation is a communication tool that is used to facilitate the way visitors engage with the places they visit [1]. According to Armstrong and Weiler [14], it is originally defined by Freeman Tilden as an educational activity aimed at revealing meanings and relationships to people about the places they visit and the things they see and do there [8]. As his definition suggests, Tilden saw interpretation as an approach to communication in which the main aim is the meaning-making and the revelation of relationships in the visitor's mind rather than the mastering of isolated facts and figures [13]. The philosophical elements of his original principles of interpretation are still becoming relevant to many other researchers' later models of interpretation, even though it is more than 50 years old. Since then, there is mounting evidence that effective personal (face-to-face) interpretation makes a positive impact on visitor leisure experiences [4,6,12, 15-17]. For example, Ham and Weiler [6], found that the higher global satisfaction of 727 national and international visitors with five interpretive services in the Panama Canal Watershed was due primarily to their satisfaction with the interpretive dimensions of their visit, as opposed to other services and setting attributes. As a communication tool, interpretation focuses on managing visitor behaviour and enhancing visitor experience [14, 18-20].

About two decades ago, in the context of environmental and conservation purposes, Sam [1] developed a model of thematic interpretation which he defines it as translating the technical language of natural science or related field into terms and ideas that people aren't scientists can readily understand and it involved doing it in a way that was entertaining and interesting to these people. His model was based on four essential components listed as being enjoyable, relevant, organised and thematic which formed the acronyms of EROT. Firstly, it needs to be enjoyable (E) so that people need to be motivated to engage with the interpretation. Secondly, it needs to be relevant (R) to visitors; that is providing stories and concepts so that people can connect to the park through their own experience. Thirdly, it needs to be organized $(\mathrm{O})$ and provide a clear structure to guide visitors through the programme. Finally, interpretation needs to be thematic (T) and provide a message that visitors will remember following their visit. a fundamental premise of thematic interpretation is that once visitors take away with them a range of intangible values, from memories, to thoughts, understandings and new perspectives, then the place matter to them. This led to higher level of satisfaction, word-of-mouth promotion and repeat visitors or results in higher visitor spending on site. He argued that the first three components were applicable to any form of entertainment and that, if the aim of interpretation was to influence visitor's attitudes towards the role of protection agencies, or to form personal connections to the park, then it was through the thematic component that park managers or park guides must work. Recently, drawing on a growing body of research in cognitive and behavioural science, Ham [4] revised his EROT model of interpretation to his new theoretical model of thematic interpretation called TORE model. By taking the heart of Tilden's definition of interpretation, Ham [14] defines interpretation in his latest book-"Interpretation - Making a Difference on Purpose" as a mission-based approach to communication aimed at provoking in audiences the discovery of personal meaning and the forging of personal connections with things, places, people, and concepts. He stated that the best interpretation engaged the visitor both intellectually and emotionally and that it was personal, relevant and meaningful to them. He argued that by presenting a strong theme in an enjoyable, relevant and organized (ERO) way gave the tour guides or park guides a better chance of making a purposeful difference in how visitors think, feel and possibly behave with respect to the things they interpreted.

\section{Design and Methodology}

The present study utilised a five minute self-administered questionnaire using a non-probability, random and purposive sampling approaches. The study adopted a well-designed with a high levels of 
reliability and validity set of indicators and survey instrument developed, tested and refined by Weiler and Ham $[21,22]$ used to evaluate the outcomes of face-to-face interpretation across a range of naturebased visitor setting and experience. The questionnaire was administered to selected park guides' visitors of 18 years and above at Bako National Park, Sarawak, East Malaysia at the end of each guided tours, delivered by purposively sampled park guides. The questionnaire measured on a 7bipolar numerical scale was organised into the following ten indicators or competencies (see Table I) :

Table 1. Nature Interpretation Indicators (adopted from [21, 22])

\begin{tabular}{|c|l|c|c|}
\hline Indicator & \multicolumn{1}{|c|}{ Indicator Long Title } & $\begin{array}{c}\text { No. of } \\
\text { items }\end{array}$ & $\begin{array}{c}\text { Reliability } \\
\text { (alpha) }\end{array}$ \\
\hline A & $\begin{array}{l}\text { Impact on appreciation of indigenous connections with } \\
\text { nature }\end{array}$ & 4 & 0.95 \\
\hline B & Elaboration (provoked to thought) & 5 & 0.88 \\
\hline C & Positive attitude toward nature conservation & 3 & 0.73 \\
\hline D & Positive global evaluation of interpretation at site & 1 & NA \\
\hline E & Desire to participate in additional interpretive activities & 1 & NA \\
\hline F & Desire to purchase a memento or sovenir & 1 & NA \\
\hline G & Desire to stay longer & 1 & NA \\
\hline H & Desire to return for repeat visit & 5 & 0.90 \\
\hline I & Positive word-of-mouth advertising & 4 & 0.67 \\
\hline J & Visitor found it relevant and meaningful to their lives & & \\
\hline
\end{tabular}

For the purpose of this paper, the analysis only focused on to the outcomes of the elaboration (provoke to thought) sub-indicators, positive global evaluation of interpretation at site sub-indicators and positive word-of mouth advertising sub-indicators of the guided tours at Bako National Park as they are correlatedly contributing to the outcomes of visitor experience enhancement. The data collected were reviewed, tabulated and analyzed using the Statistical Package for Social Science (SPSS) version 21.

\section{Results and Discussion}

A total of 300 questionnaires were distributed to visitors of purposively sampled park guides. Of this, 203 respondents were deemed as valid and useful. This represent a $67 \%$ response rate, which is acceptable for questionnaire surveys [23]. Out 29 items measuring the ten indicators as indicated in Table I, 14 items that were directly related to visitor experience and satisfaction level (i.e., elaboration (provoke to thought), 4 items of positive global evaaluation of interpretation at site, and 5 items related to word-of-mouth advertising) were examined with descriptive statistic analysis and correlation analysis to explore, summarise and describe the data collected; and establish relationship between variables in a linear fashion. 


\subsection{Demographics Patterns}

Out 203 respondents, 48 per cent were male and 52 percent females, with majority of them were foreigners $(87 \%)$ and Malaysians (12\%). Most of the participants were foreigners from a European countries. From the yearly statistic, the fact that about $80 \%$ of visitors visiting Bako National Park were foreigners. A majority of these respondents $(97 \%)$ were first timers visiting Bako National Park and a first timer as well (87\%) in visiting other protected areas in Sarawak. In term of age braket, $12 \%$ of them were young people of 18 to 25 years, $32 \%$ of 26 to 40 years, $34 \%$ of 41 to 55 years and $19 \%$ of 56 years and above. About $57 \%$ of them were married and $38 \%$ single visitors. Nearly $16 \%$ of the sample $(15.5 \%)$ had at least some high school education, with $22 \%$ earning a diplomas and technical education, $18 \%$ earning a bachelors degree and $41 \%$ earning a post graduates degree. In term of employment, about $43 \%$ of the respondents came from private sectors, $21 \%$ were government employees and the rest were from self employment and students.

\subsection{Effectiveness of Thematic Interpretive Guided Tours}

The reliability and validity of the measurement of scale was not tested for all the 10 indicators of interpretation effectiveness evaluation as the same measurement was adopted from a well-designed, tested and refined survey instrument developed by Weiler and Ham [22]. The evaluation of effectiveness of interpretive guided tours based on ten indicators were analyzed using descriptive statistic and correlation analysis at one percent significant level $(\alpha=0.01)$.

\subsubsection{Global Evaluation of Interpretation of Bako National Park}

According to Ham [12], the quality of the visitors' experiences is very much affected by the quality of the guide's performance as well as on indicators pertaining to interpretation methods and conservation theme. The main way the guides can enhance visitors' experiences is to influence how much those people think, what they think about, and how they feel about it through interpretation and this can be measured using the four sub-indicators of the positive global evaluation of interpretation of the site [22] related to the level of enjoyment, quality of guided tours, level of satisfaction, level of interestingnesss of guided tours (Table 2). From the descriptive statistic analysis, all the four subindicators indicated that the mean scores of the sub-indicators of the global evaluation of interpretation effectiveness were in the range of 6.52 to 6.61 of a 7-bipolar numerical scales. The result shows the highly enhanced visitor experiences were achieved by the fact of the highly satisfied respondents participated in thematic interpretive guided tours at Bako National Park. This findings support Ham, Housego and Weiler [15] in which creating satisfied visitors was central to success for anyone who guide visitor where positive experiences produced satisfied visitors.

Table 2. Sub-indicators of Positive Global Evaluation of Interpretation at Bako National Park

\begin{tabular}{|l|c|c|c|c|c|}
\hline \multicolumn{1}{|c|}{ Sub-Indicators } & $\mathrm{N}$ & Minimum & Maximum & Mean & Std. Deviation \\
\hline Enjoyable guided tour & 203 & 2 & 7 & 6.51 & .892 \\
Good guided tour & 203 & 2 & 7 & 6.61 & .785 \\
Satisfied guided tour & 203 & 2 & 7 & 6.47 & .810 \\
Interesting guided tour & 203 & 1 & 7 & 6.52 & .930 \\
Valid N (listwise) & 203 & & & & \\
\hline
\end{tabular}


From the frequency table (table 3), about $62 \%$ of the respondents were very satisfied with their thematic interpretive guided tours while $26 \%$ were moderately satisfied. The result showed a high degree of satisfaction level especially among the respondents, especially among the foreigners. The high degree of satisfaction level is further supported by the positive association of good quality of guided tours (Table 4). The Pearson's product-moment correlation indicated that higher level of interesting guided tour scores were positively associated with good quality of guided tour scores $(\mathrm{r}=$ $.636, \mathrm{p}<0.01)$. The correlation of 0.636 also indicated that the variables explain the variance in one another to the extend of $40.4 \%\left(0.636^{2}\right)$ and the probability of this relationship not being true is $1 \%$ or less.

Table 3. Satisfaction Level of Thematic Interpretive Guided Tours

\begin{tabular}{|l|r|r|r|r|}
\hline & Frequency & Percent & $\begin{array}{c}\text { Valid } \\
\text { Percent }\end{array}$ & $\begin{array}{c}\text { Cumulative } \\
\text { Percent }\end{array}$ \\
\hline Moderately not satisfying & 2 & 1.0 & 1.0 & 1.0 \\
Neither satisfying nor not & 5 & 2.5 & 2.5 & 3.4 \\
satisfying & 16 & 7.9 & 7.9 & 11.3 \\
Slightly satisfying & 54 & 26.6 & 26.6 & 37.9 \\
Moderately satisfying & 126 & 62.1 & 62.1 & 100.0 \\
Very satisfying & 203 & 100.0 & 100.0 & \\
\hline
\end{tabular}

Table 4. Correlations Coefficient of Guided Tour Quality and its Interestingness

\begin{tabular}{|ll|r|r|}
\hline & Pearson Correlation & $\begin{array}{c}\text { Good or bad } \\
\text { guided tour }\end{array}$ & \multicolumn{2}{|c|}{$\begin{array}{c}\text { Interestingness of } \\
\text { guided tour }\end{array}$} \\
\hline Good guided tour & Sig. (1-tailed) & 1 & $.636^{* *}$ \\
& $\mathrm{~N}$ & 203 & .000 \\
& Pearson Correlation & $.636^{* *}$ & 203 \\
Interesting & Sig. (1-tailed) & .000 & 1 \\
guided tour & $\mathrm{N}$ & 203 & 203 \\
& & & \\
\hline
\end{tabular}

**. Correlation is significant at the 0.01 level (1-tailed).

\subsubsection{Sub-indicators of Elaboration (provoke to thought)}

The sub-indicators of the elaboration (provoke to thought) measured the amount of thinking the thematic interpretation provoked visitors to engaged in. When visitors are provoked to thought, they have been moved to make connections between the topic being interpreted and what they already know and feel [6]. When this happened, experiences are enhanced and visitors returned home with positive things to say about the place and the time they spent there [15]. This was accomplished with five strongly reliable measurements (sub-indicators) as in Table 5. 
Table 5. Descriptive Statistics - Sub-Indicators of Elaboration (provoke to thought)

\begin{tabular}{|l|c|c|c|c|c|}
\hline Sub-Indicators & N & Minimum & Maximum & Mean & $\begin{array}{c}\text { Std. } \\
\text { Deviation }\end{array}$ \\
\hline Make visitor curious. & 202 & 1 & 7 & 6.09 & 1.195 \\
Make visitor think. & 203 & 1 & 7 & 6.17 & 1.065 \\
Make visitor want to talk about what & 203 & 2 & 7 & 6.28 & 1.001 \\
he/she had heard. & 203 & 2 & 7 & 6.34 & .969 \\
Make visitor want to know more & 203 & 3 & 7 & 6.41 & .787 \\
Intrigued visitor & 202 & & & & \\
Valid N (listwise) & & & & & \\
\hline
\end{tabular}

The result of the descriptive statistic analysis of the sub-indicators of the elaboration (Table 5) showed that the five means were highly measured, ranging from moderate 6.09 to 6.41 of the 7bipolar numerical scale. Therefore, the result for these sub-indicators showed a strong indication of how much the thematic interpretive guided tours had successfully provoked visitors to process new thoughts about the things the guide interpret.

The bivariate correlations performed using Pearson's product-moment correlation between the quality of guided tour scores (good or bad) and visitor satisfaction level scores (Table 6) also showed a positive relation between the variables, where the result of the correlation indicated that higher level of visitor satisfaction scores were positively associated with good quality of guided tour scores $(\mathrm{r}=$ $.528, \mathrm{p}<0.01)$. The correlation of 0.528 also indicated that the variables explain the variance in one another to the extend of $29.9 \%\left(0.528^{2}\right)$ and the probability of this relationship not being true is $1 \%$ or less. This result showed that thematic interpretive aspects of the visit contributed positively to visitor's satisfaction with their experience. According to Ham, Housego and Weiler [15], enhancing visitor experiences through thematic interpretation can lead to other kinds of outcomes that were of special interest to park management authority and private tourism businesss, for examples, visitors provoked to think about the things they see and do in a visitor destination often intended to return for another visit in future. This was supported by a result of descriptive statistic which revealed that where nearly $94 \%$ of the respondents (93.6\%) indicated their intention to revisit Bako National Park in future (Table 8). As tourism business is all about selling experience, thus, the result of this study support the notion that the revenue of tourism businesses can only be assured when the tour operators and interpretive guides provide exciting and pleasant experiences to tourists, which in turn, significantly affect their satisfaction and their evaluations of a particular service [25].

Table 6. Correlations of Good Guided Tour Scores and Visitor Satisfaction Scores

\begin{tabular}{|c|c|c|c|}
\hline & & $\begin{array}{c}\text { Quality of } \\
\text { Guided Tours }\end{array}$ & $\begin{array}{l}\text { Satisfaction level of } \\
\text { guided tours }\end{array}$ \\
\hline \multirow{3}{*}{ Good guided tours } & Pearson Correlation & 1 & $.582^{* *}$ \\
\hline & Sig. (1-tailed) & & .000 \\
\hline & $\mathrm{N}$ & 203 & 203 \\
\hline \multirow{3}{*}{$\begin{array}{l}\text { Satisfaction level of guided } \\
\text { tours }\end{array}$} & Pearson Correlation & $.582^{* *}$ & 1 \\
\hline & Sig. (1-tailed) & .000 & \\
\hline & $\mathrm{N}$ & 203 & 203 \\
\hline
\end{tabular}


Table 7. Correlations: Visitor Satisfaction Level Scores and Word of Mouth Recommendation Scores

\begin{tabular}{|ll|r|r|}
\hline & \multicolumn{1}{|c|}{$\begin{array}{c}\text { Satisfaction } \\
\text { level of guided } \\
\text { tours }\end{array}$} & $\begin{array}{c}\text { Recommend other } \\
\text { people to visit Bako }\end{array}$ \\
\hline Satisfaction level of guided & Pearson Correlation & 1 & $.436^{* * *}$ \\
tours & Sig. (1-tailed) & 203 & .000 \\
& $\mathrm{~N}$ & $.436^{* *}$ & 203 \\
& Pearson Correlation & .000 & 1 \\
$\begin{array}{l}\text { Recommend other people to } \\
\text { visit Bako }\end{array}$ & Sig. (1-tailed) & 203 & 203 \\
& $\mathrm{~N}$ & & \\
\hline
\end{tabular}

**. Correlation is significant at the 0.01 level (1-tailed).

Table 8. Respondents Intended to Return for Another Visit to Bako National Park in Future

\begin{tabular}{|cc|c|c|c|c|}
\hline & & Frequency & Percent & Valid Percent & Cumulative Percent \\
\hline \multirow{4}{*}{ Valid } & Yes & 190 & 93.6 & 93.6 & 93.6 \\
& No & 13 & 6.4 & 6.4 & 100.0 \\
& Total & 203 & 100.0 & 100.0 & \\
\hline
\end{tabular}

Likewise, the impact of higher scores for respondents to recommend other people to visit Bako National Park (Table 7) are positively associated with higher visitor satisfaction scores $(r=.436, p<$ 0.01). The benefits of this positive association are the positive probability of an increased visitor spending and employment in tourism sector in near future. Therefore, in the context of Bako National park, Sarawak, Malaysia good quality of thematic interpretive guided tours has been proven as an effective management tool to assist the enhancement of visitor experiences which in turn can lead to other kinds of affective and behavioural outcomes that are of special interest to many stakeholders and private tourism businesss [15].

\section{Conclusion}

With ecotourism is increasingly being promoted in association with the management of protected area and where it is regarded as a positive force for conservation and sustainable development especially in developing countries [20, 24], coupled with visitors becoming increasingly sophisticated and demanding in their travel need and wants, the industry must respond with a wider range of choice and higher quality product while providing an enjoyable experience in the context of ecological and cultural responsibility. They want a holiday filled with the kind of activities that they want to do in their leisure time and value for money, something they have always wanted to do but never got the time or opportunity for. Nobody wants to go to destination and waste away the time. One of the key strategies to address these wide range of visitor's increasing demanding interests is the frequent reliance of tour guides or park guides, utilising the principle of TORE-model of interpretation which was considered by many researchers as a world best communication approach to assist in enhancing visitor experiences, influencing attitudes and promoting appreciation, and strengthening protection of 
important rare or fragile resource [13]. The results of these highly measured means of sub-indicators of global evaluation of interpretation of site and elaboration, and positive association of variables from the correlation coefficient have supported and strengthened other researchers' findings on the important of a thematic interpretation as a management tool for both conservation and tourism $[5,18]$. From this study, it can be concluded that thematic interpretation approach of communication is an important visitor management and marketing tools for both protected area managers and tourism business in Sarawak, Malaysia. The results of this study also indicate that there are scopes for further empirical research on the effects of thematic interpretation in a more adaptive approach in the developing countries, not only in the context of enhancing visitor experience, but also in influencing visitor behaviour, and protecting fragile resource in protected areas in a safe, culturally and environmentally sustainable manner.

\section{References}

1. S. H. Ham, Environmental Interpretation-A Practical Guide for People with Big Ideas and Small Budgets. Golden, CO, USA: Fulcrum Publishing/North American Press (1992)

2. S.H. Ham, Meaning Making - The Premise and Promise of Interpretation. Keynote address to Scotland's First National Conference on Interpretation, Royal Botanic Gardens, Edinburgh, April 4 April 2002.

3. S. H.Ham, Ecotourism - Making a Difference by Making Meaning. Keynote address to the Ecotourism Association of Australia, 10 November 2003.

4. S. H.Ham, Can Interpretation Really Make a Difference? Answers to four questions from Cognitive and Behavioural Psychology. In Proceedings, Interpreting World Heritage Conference, 25-29 March 2007 Vancouver, Canada. Fort Collins, USA: National Association of Interpretation, 42-52.

5. S.H. Ham, E. K.Sandberg, Interpretation as strategic communication in protected area management. A paper presented in the $6^{\text {th }}$ International conference on Monitoring and Management of Visitors in Recreational and Protected Areas, Stockholm, Sweden, 132133(2012)

6. S.H.Ham, B.Weiler, Isolating the Role of On-site Interpretation in a Satisfying Experience. Journal of Interpretation Research, 12, 2, 5-24 (2007)

7. J.L.Tarlton, C.J.Ward, The Effect of Thematic Interpretation on a Child's Knowledge of and Interpretive Program. Journal of Interpretation Research, 11, 1, 7-33 (2006)

8. F.Tilden, Interpreting Our Heritage. Chapel Hill, NC: University of North Carolina Press (1977)

9. S.H. Ham, B.Weiler, 100,000 Beating Bird Hearts: Tourism, Wildlife and Interpretation. Keynote Presentation at the first National Conference on Wildlife Tourism in Australia, Hobart, Tasmania, Australia, 28 - 30 October 2001.

10. R. Black, S.H.Ham, B.Weiler, Ecotour Guide Training in Less Developed Countries: Some Preliminary Research Findings. Journal of Sustainable Tourism, 9, 2, 147-156 (2001)

11. K.Rodger, S.A.Moore, R.Taplin, Visitor satisfaction, loyalty and protected areas : a review and the future. A report prepared for WA Department of Environment and Conservation, Parks Victoria and the Park Forums, Australia (2012).

12. S.H.Ham, From Interpretation to Protection: Is There a Theoretical Basis? Journal of Interpretation Research, 14, 2, 48-58 (2009)

13. S.H.Ham, Interpretation - A Guide for Making a Difference on Purpose. Fulcrum Publishing Golden, Colorado (2013).

14. K.Armstrong, B.Weiler, Improving the tourist experience: Evaluation of interpretation components of guided tours in national parks, CRC for Sustainable Tourism, Gold Coast (2003).

15. S.H.Ham, A.Housego, B.Weiler, Tasmanian Thematic Interpretation Planning Mannual. Tourism Tasmania, Australia (2005) 
16. R.Powell, S.H.Ham, Can ecotourism interpretation really lead to pro-conservation knowledge, attitudes and behaviors? Evidence from the Galapagos Islands. Journal of Sustainable Tourism, 16, 4, 467-489 (2008)

17. B.Weiler, S.H.Ham, Tour guides and interpretation. In Weaver, D. (Ed.), The encyclopedia of ecotourism, Walingford, UK: CAB International, 549-563 (2001)

18. C. Littlefair, C. Buckley, Interpretation reduces ecological impacts of visitors to world heritage site. Ambio, 37, 5, 338-341 (2008)

19. E.M.P.Madin, \& M. Fenton, Environmental Interpretation in the Great Barrier Reef Marine Park: An Assessment of Programme Effectiveness. Journal of Sustainable Tourism, 12, 2, 121 137 (2004)

20. M.B. Orams, Using Interpretation to manage nature-based tourism. Journal of Sustainable Tourism, 4, 2, 81-93 (1995)

21. B.Weiler, S.H. Ham, Development of a Research-Based Tool for Evaluating Interpretation (STCR Technical Report). Brisbane, Australia: Sustainable Tourism Cooperative Research Centre (2006).

22. B. Weiler, S.H. Ham, S.H., Development of a Research Instrument for Evaluating the Visitor Outcomes of Face-to-Face Interpretation, Visitor Studies, 187-205 (2010)

23. U.Sekaran, R. Bougie, Research Methods for Business: A skill Building Approach. A John Wiley and Sons, Ltd. Publication (2010)

24. B.Weiler, S.H. Ham, Toward a theory of quality in cruise-based nature guiding. Journal of Interpretation Research 7, 2, 29-49 (2002)

25. J.H. Kim, Determining the factors affecting the memorable nature of travel experiences. Journal of Travel \& Tourism Marketing, 27, 780-796 (2010) 